\title{
Immune and parasitological response in horses infected with gastrointestinal nematodes in the humid tropic of Mexico
}

\section{Respuesta inmune y parasitológica de caballos infectados con nematodos gastrointestinales en el trópico húmedo de México}

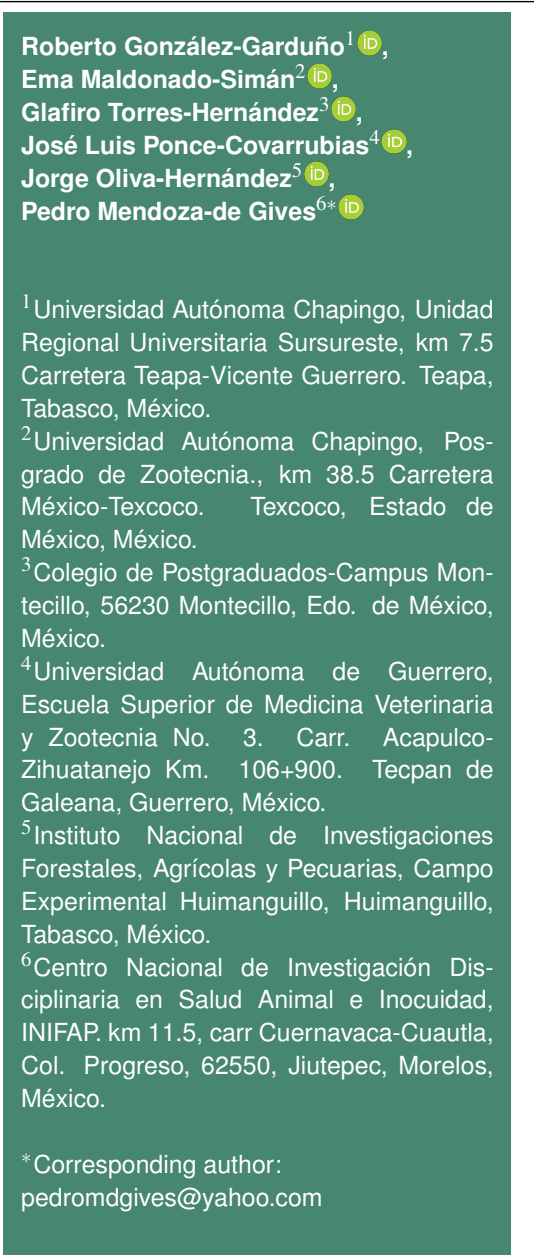

Scientific article

Received: July 22, 2020

Accepted: March 11, 2021

How to cite: González-Garduño R, Maldonado-Simán E, Torres-Hernández G, Ponce-Covarrubias JL, Oliva-Hernández $\mathrm{J}$, Mendoza-de Gives P (2021) Immune and parasitological response in horses infected with gastrointestinal nematodes in the humid tropic of Mexico. Ecosistemas y Recursos Agropecuarios 8(1): e2687. DOI: 10.19136/era.a8n1.2687
ABSTRACT. The objective of the study was to determine the parasitological and immune response in horses naturally re-infected with gastrointestinal nematodes (GIN) after anthelmintic treatment in the humid tropic of Mexico. The study was conducted in Tenosique, Tabasco, Mexico. A total of 30 horses were sampled monthly for nine months. Fecal samples were obtained to determine the number of nematode eggs per gram (EPG) of feces. Stool cultures were performed to obtain and identify infective larvae (L3) genera. Blood samples were also obtained to determine the packed cell volume (PCV), the total plasma protein (TPP), and the differential leukocyte count (DLC). Serum enzyme-linked immunosorbent assays (ELISA) were performed to determine IgA levels against adult cyathostomins and Strongylus nematode antigen. The analyses considered the age and gender of the horses, and the season (Cold, rainy and dry). The number of EPG and TPP were higher in females (1224 \pm 1269 and $7.6 \pm 0.6 \mathrm{gdL}^{-1}$, respectively) than males $(623 \pm 671$ and $7.4 \pm 0.5$ $\mathrm{gdL}^{-1}$, respectively), and no differences were observed with animal age $(p>0.05)$. The number of EPG increased in the rainy season. The main nematodes involved were of the subfamily Cyathostominae (97.4\%) and to a lesser degree of species Strongylus equinus, $S$. edentatus, S. vulgaris, and Oxyuris equii. The season affected the leukocytes, neutrophils, and lymphocytes counts but not eosinophils. Variables such as gender, animal age, and environmental conditions are important elements for a diagnosis of GIN and the application of treatments for its control.

Key words: Cyathostomins; equines; immunoglobulins; parasites; Strongylus.

RESUMEN. El objetivo fue determinar la respuesta parasitológica e inmune en caballos reinfectados naturalmente con nematodos gastrointestinales (NGI) posterior a la desparasitación en el trópico húmedo de México. El estudio se realizó en Tenosique, Tabasco, México. Se utilizaron 30 caballos muestreados mensualmente durante nueve meses. Se determinó el número de huevos por gramo de heces (HPG). Se realizaron coprocultivos para obtener e identificar larvas infectivas (L3). Se obtuvieron muestras de sangre para determinar el volumen celular aglomerado (VCA), proteína plasmática (PPT) y el conteo diferencial de leucocitos (CDL). Se realizaron ensayos de inmuno absorción enzimática (ELISA) en suero para determinar los niveles de IgA contra antígenos de Ciatostómidos y de Strongylus. Los análisis consideraron la edad y el género, también se estudió la época (fría, lluviosa y seca). El número de HPG y PPT fueron más altos en las hembras (1224 \pm 1269 y $7.6 \pm 0.6 \mathrm{gdL}^{-1}$, respectivamente) que en los machos (623 \pm 671 y $7.4 \pm 0.5 \mathrm{gdL}^{-1}$, respectivamente), y no se observaron diferencias con la edad del animal $(p>0.05)$. El número de HPG aumentó en la temporada de lluvias. Los principales nematodos fueron de la subfamilia Cyathostominae (97.4\%) y en menor grado las especies Strongylus equinus, S. edentatus, S. vulgaris, y Oxyuris equii. La época afectó el conteo de leucocitos, neutrófilos y linfocitos, pero no eosinófilos. Las variables como el género, edad animal y las condiciones ambientales son elementos a considerar para un diagnóstico de NGI y la aplicación de tratamientos para su control.

Palabras clave: Cyathostomidos; equinos; inmunoglobulinas; parásitos; Strongylus. 


\section{INTRODUCTION}

In Mexico, horses are considered as an essential species, since they participate in a number of human activities, such as transportation (Seyoum et al. 2015), herding cattle, carrying wood and recreational activities (Domínguez-Sánchez et al. 2015). Parasitic diseases are common in equines around the world and are some of the most important threatens to the health of horses.

Gastrointestinal nematodes (GIN) affecting horses, those belong to subfamilies Strongylinae and Cyathostominae have a prevalence above 70\% (Khan et al. 2015, Seyoum et al. 2015). They are found in large populations that can cause severe pathological effects. The clinical signs that occur in equines are weight loss, diarrhea, colic, pyrexia, depression, and hypoalbuminemia. The high frequency of GIN occurs in warm climates where environmental conditions favor the proliferation of this kind of parasite (Khan et al. 2015). In addition, the management systems can influence the infection of various parasites (Musa et al. 2016). Consequently, understanding the population dynamics of larvae can be used to design rational anthelmintic control programs. Previous studies indicated that there was a high rate of re-infection with GIN in southeast Mexico (González-Garduño et al. 2015) and in many other parts of the world (Fritzen et al. 2010). The most common control measurement has restricted to the use of anthelmintic drugs, but the continuous use has favored an increased resistance in the main nematode species that parasitize horses (Andersen et al. 2013, Matthews, 2014).

In Mexico, a few studies have focused on determining the impact of GIN on equine health conditions (Valdéz-Cruz et al. 2013) and although is well known that immune response of foals is different from adults, and several specific immunological parameters influence the different immunity results in young foals (Perkins y Wagner 2015) it is required to confirm the parasitological response in the health of equines in conditions of the tropic of Mexico, by this reason the objective of this study was to determine the parasitological and immune response of horses to naturally re-infection with gastrointestinal nematodes after an- thelmintic treatment, in humid and warm weather conditions.

\section{MATERIALS AND METHODS}

\section{Location}

The study was conducted in one farm located in Tenosique, Tabasco, Mexico, at $17^{\circ} 28^{\prime} 21^{\prime \prime} \mathrm{N} 91^{\circ} 25^{\prime}$ $36 " \mathrm{~W}$. The climate in the region is warm and humid, with an average annual temperature of $27.6{ }^{\circ} \mathrm{C}$ and an average rainfall of $2131 \mathrm{~mm}$ per year (CONAGUA 2019).

\section{Animal Management}

One herd of 30 horses from the same farm (12 females and 18 males) were followed for 9 months from December to August 2017, which correspond to the cold (December, January, February), dry (March, April and May) and rainy (June, July and August) season of the region. The whole herd was studied so that animals of different ages were used, classifying them as young ( $0-1$ year), mature ( 1 to 7 years) and old ( $>7$ years); the females were kept for breeding and some males were gelds or stallions depending on their size and the decision of the owner according table 1.

Table 1. Horses used in the parasitological and immunological study.

\begin{tabular}{ccccc}
\hline Category & Females & Males & $\begin{array}{c}\text { Total } \\
(\mathrm{n})\end{array}$ & $\begin{array}{c}\text { (n) } \\
(\mathrm{n})\end{array}$ \\
\hline Young & $0.6-1$ & 3 & 1 & 4 \\
Mature & $1-7$ & 2 & 5 & 7 \\
Old & $>7$ & 7 & 12 & 19 \\
Total & & 12 & 18 & 30 \\
\hline
\end{tabular}

The horses are used in activities related to the cattle herd management. They grazed as a single herd together with beef cattle on 50 hectares of low-sized grasses like: Paspalum notatum and Paspalum conjugatum pastures, some paddocks have African star grass (Cynodon nlemfuensis) in Gmelina (Gmelina arborea) plantations where animals had the function of keeping the grass controlled in a silvopastoral system. The farmer reported that the horses were not supplemented and three months before starting the study they had not been dewormed. On 
the farm it is customary to deworm with ivermectin paste every year without making a previous diagnosis, so this study is important to determine the genera of nematodes that prevail in the area. The animals were used for work activities (cattle herding) but were mostly allowed to spend their time grazing.

\section{Determination of anthelmintic efficacy}

At the beginning of the study, 20 horses were dewormed with Pyrantel Pamoate (Exodus-Paste, Bimeda) at a dose of $3 \mathrm{mg} \mathrm{kg}^{-1}$ body weight (BW) to determine the efficacy by the fecal egg count reduction test (FECRT). One group of 10 horses without deworming represented the control group. The FECRT percent efficacy used by Dobson et al. (2012) were calculated as: FECRT $=100 \times\left[\left(1-\frac{T 2}{T 1}\right) \times\left(\frac{C 1}{C 2}\right)\right]$. Where $\mathrm{T} 1$ represents the mean pre-treatment and T2 the fecal nematode egg counts performed at 15 and 45 days post treatment of a treated group, and $\mathrm{C} 1$ and $\mathrm{C} 2$ represent the mean pre and post-treatment counts of an untreated control group, respectively.

\section{Determination of re-infection level}

At the end of the anthelmintic efficacy study (45 days), the horses were not dewormed again. The horses were enclosed in a handling sleeve and the feces sample was obtained directly from the rectum of the animals monthly for nine months (December to August). The number of EPG in feces was determined using a saturated solution of sodium chloride with the McMaster technique (Thienpont et al. 2003) with a sensitivity of 50 EPG. Stool cultures were performed on positive samples for nematode eggs, keeping feces at room temperature in containers, covered with gauze and adding water every third day to maintain the moisture. After eight days, the feces were placed in Baermann apparatus to obtain the infective larvae (Thienpont et al. 2003) and subsequently the taxonomic identifying was based on the number of intestinal cells as the main characteristic, since the size and shape are very similar (Bowman 2011). To obtain pinworms (Oxyuris equi), the Graham Test Technique was used, briefly, the anal mucus sample is collected on rubberized tape and deposited on slides.

The blood samples were obtained by punc- ture of the jugular vein and collected in tubes with ethylenediamine tetraacetic acid (EDTA). With whole blood the packed cell volume (PCV) was processed by the micro-hematocrit method (\%), also plasma protein (TPP) was determined with a refractometer. Also, thin blood smears were stained with a staining kit (rapid blood stain, Hycel) to determine the differential leukocyte count in which 100 leukocytes were classified as neutrophils, eosinophils, basophils, monocytes and lymphocytes and expressed as percentage.

\section{Antigen preparation}

Crude worm antigen (CWA) from adult nematode of Strongylus spp. and cyathostomins was prepared. Adult nematodes were collected from the intestine of one horse in a post mortem nematode diagnosis. The worms were washed in PBS with $0.01 \%$ sodium azide and grinding with $10 \% 1 \mathrm{mM}$ phenylmethylsulphonyl fluoride (PMSF), and $2 \%(\mathrm{w} / \mathrm{v})$ reduced Triton X-1060. Protein samples were concentered by centrifugation at $20000 \times \mathrm{g}$ per $20 \mathrm{~min}$ at $4{ }^{\circ} \mathrm{C}$. The supernatant, containing CWA was collected and stored at $-20{ }^{\circ} \mathrm{C}$. The protein concentration was estimated by the Bradford method (Bradford, 1976) constructing a calibration curve and determining the protein concentration of the sample with Coomassie Protein Assay Kit (Thermo Fisher Scientific, USA).

Antigen preparation of Strongylus spp. and Cyathostomins and immune-enzymatic assay were according to a widely description in other study (González-Garduño et al. 2017). Results were expressed as the percentage of the Optical density (OD) of the positive control serum and employing the following formula (Cardoso et al. 2013):

$$
\% \mathrm{OD}=\left[\frac{(O D \text { mean of the tested serum }-O D \text { negative control serum })}{(O D \text { mean of the positive control serum }-O D \text { mean negative control serum })}\right] \times 100
$$

\section{Statistical Analysis}

The data analysis considered the gender of the animal, the season of sampling, and the age of the animal as the main factors and some interactions were tested using de SAS program (SAS 2017) with the following model:

$Y_{i j k l}=\mu+\rho_{i}+\zeta_{j}+\psi_{k}+\rho * \zeta_{i j}+\rho * \psi_{i k}+\zeta * \psi_{j k}+\rho * \zeta * \psi_{i j k}+\varepsilon_{i j k l}$

Where: $Y_{i j k l}$ is the response variable (EPG, 
leukocyte count, $\lg A), \mu$ is the general mean, $\rho_{i}$ is the fixed effect of the season ( $i=$ cold, rainy, dry), $\zeta_{j}$ is the fixed effect of the $j^{\text {th }}$ horse age (young, mature, old), and $\psi^{k}$ is the fixed effect of the $\mathrm{k}^{\text {th }}$ gender (male or female). The interactions are $\rho^{\star} \zeta_{i j}, \rho^{*} \psi_{i k}, \zeta^{*} \psi_{j k}$, and $\rho^{*} \zeta^{*} \psi_{i j k} . \varepsilon_{i j k l}$ is experimental error. The means separation was carried out using Tukey test. Spearman correlations were made to known the relation between variables in overall data. Only for correlations, the age was recorded as a discrete variable in days.

\section{RESULTS}

\section{Fecal egg count reduction test}

After 15 days of anthelmintic treatment, the FECR was $96.4 \%$. The number of EPG at the beginning of the study was $1319 \pm 571$, compared with the control group that was $593 \pm 567$ EPG. After the anthelmintic treatment the number of EPG of treated group diminished to $95 \pm 104 \mathrm{EPG}$ and the control was $1178 \pm 1172 \mathrm{EPG}$.

\section{Eggs per gram of feces and immune response}

In rainy and cold seasons, the number of EPG shows the highest values when high humidity was recorded in the region (Table 2). In addition, differences in number of EPG and TPP were found by the gender of the animals $(p<0.01)$. Females had higher number of EPG and TPP values (1224 \pm $1269 \mathrm{EPG}$ and $7.6 \pm 0.6 \mathrm{~g} \mathrm{dL}^{-1}$, respectively) than the males $\left(623 \pm 671 \mathrm{EPG}\right.$ and $7.4 \pm 0.5 \mathrm{~g} \mathrm{dL}^{-1}$, respectively), and no differences were observed with the age of the animals $(p>0.05)$.

In the humoral immune response determined by IgA levels (percentage with respect to the positive standard; \% RPS), the lowest values were observed with cyathostomins antigens used during the dry season (45.3\% RPS). Conversely, the highest levels of IgA for both antigens were observed in mature and old animals ( $>50 \%$ RPS, Table 2 ) while young animals (younger than 1.0 years old) showed the lowest IgA value (16.9\%). No differences were observed by animal gender $(p<0.05)$.
The main GIN species identified belonged to the Cyathostominae subfamily, they exhibited eight intestinal cells (97.4\%). A smaller proportion was classified into the L3 of Strongylus genus (2.6\%), and three species of this genus were identified as follows: S. equinus (16 intestinal cells), S. edentatus (20 intestinal cells), and $S$. vulgaris (30 intestinal cells). The presence of Oxyuris equi eggs was also recorded in three horses.

The season did not affect the numbers of eosinophils (1.1-1.4 cells $\times 10^{3} \mu \mathrm{L}$ ) and similar values were observed between seasons, ages, and genders $(p>0.05)$. The highest levels of leukocytes and neutrophils were observed during rainy season (18.8 and 10.5 cells $\times 10^{3} \mu \mathrm{L}$ ), while the lowest values were observed in the cold season (12.5 and 6.0 cells $\times 10^{3}$ $\mu \mathrm{L})$. On the other hand younger animals had higher leukocyte and lymphocyte counts (Table 3).

Positive correlations were observed between age and $\lg \mathrm{A}$ levels, while negative correlations occurred with white cells (leukocytes, lymphocytes and eosinophils). On the other hand, leukocytes were positively correlated with the number of lymphocytes, neutrophils and eosinophils and there were only negative correlations against $\lg \mathrm{A}$ in both antigens in dry season. The number of leukocytes also correlated positively with the number of EPG in the cold season and in the total data (Table 4).

\section{DISCUSSION}

\section{Fecal egg count reduction test}

In the present study the anthelmintic drug was efficient to control GIN infection in horses, this means that the parasites maintain their susceptibility to the drug (Matthews 2014). In a previous study carried out in this tropical region of Mexico, an anthelmintic efficiency higher than $90 \%$ in horses treated with fenbendazol was reported (González-Garduño et al. 2015).

The high efficiency of Pyrantel Pamoato obtained in the present study could be due to the low frequency of deworming in herds in this region. In addition, a low number of EPG was recorded after 45 days post-deworming (519 EPG), which could be attributed to the long prepatent period (2-3 months) of 
Table 2. Number of eggs per gram of feces, hematological values, and IgA levels in horses naturally infected under a humid, warm climate in Tenosique Tabasco, Mexico.

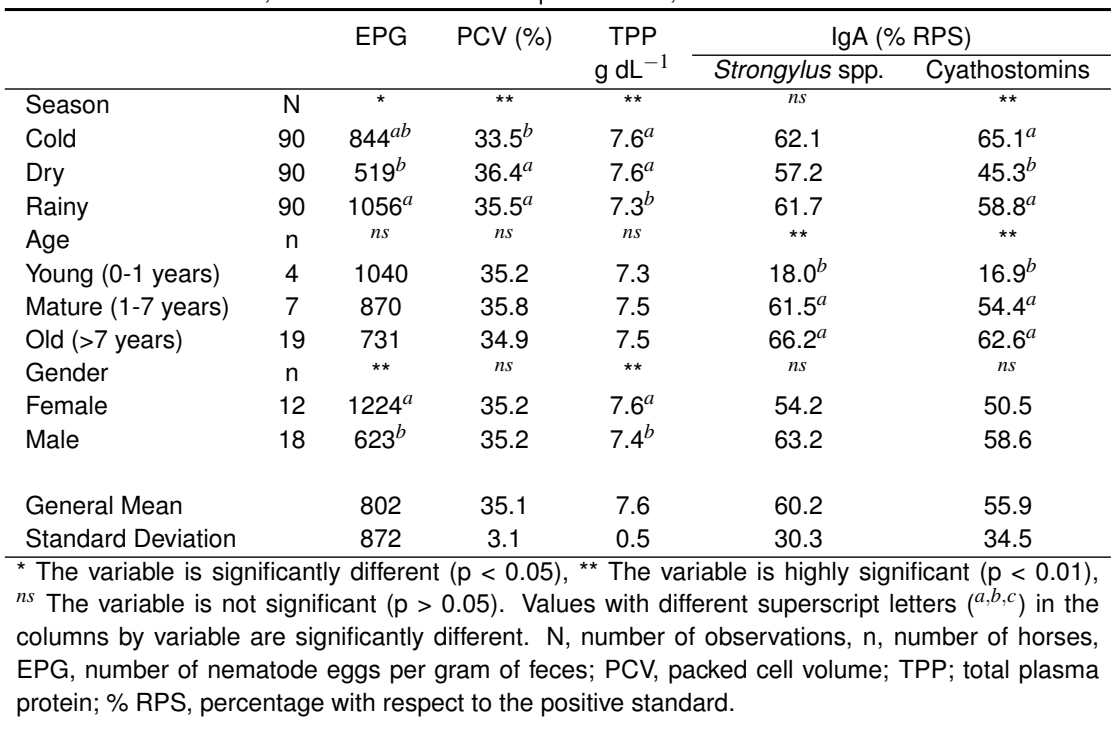

Table 3. Differential leukocyte count in horses naturally infected in humid warm conditions in Tenosique Tabasco, Mexico.

\begin{tabular}{|c|c|c|c|c|c|c|}
\hline \multirow[b]{2}{*}{ Variables } & \multicolumn{6}{|c|}{ Cellular Counts $\left(10^{3} \mu \mathrm{L}\right)$} \\
\hline & Leucocytes & Basophils & Monocytes & Neutrophils & Eosinophils & Lymphocytes \\
\hline Season & ** & ** & ** & ** & $n s$ & ** \\
\hline Cold & $12.5^{c}$ & $0.15^{c}$ & $0.09^{a}$ & $6.0^{b}$ & 1.1 & $5.3^{b}$ \\
\hline Dry & $14.6^{b}$ & $0.13^{b}$ & $0.13^{a}$ & $6.8^{b}$ & 1.4 & $6.2^{a b}$ \\
\hline Rainy & $18.8^{a}$ & $0.23^{a}$ & $0.04^{b}$ & $10.5^{a}$ & 1.3 & $6.7^{a}$ \\
\hline Age & ** & $n s$ & $n s$ & $n s$ & $n s$ & ** \\
\hline Young ( $0-1$ years) & $20.0^{a}$ & 0.19 & 0.06 & 7.0 & 1.2 & $11.5^{a}$ \\
\hline Mature (1-7 years) & $17.4^{b}$ & 0.13 & 0.07 & 9.3 & 1.2 & $6.6^{b}$ \\
\hline Old $(>7$ years $)$ & $13.8^{c}$ & 0.11 & 0.10 & 7.3 & 1.3 & $4.9^{c}$ \\
\hline Gender & $n s$ & $n s$ & $n s$ & $n s$ & $n s$ & $n s$ \\
\hline Female & 16.2 & 0.11 & 0.09 & 8.0 & 1.2 & 6.7 \\
\hline Male & 15.0 & 0.13 & 0.09 & 7.7 & 1.3 & 5.8 \\
\hline General Mean & 14.7 & 0.12 & 0.10 & 7.4 & 1.2 & 5.9 \\
\hline Standard Deviation & 3.4 & 0.14 & 0.12 & 2.9 & 0.8 & 2.4 \\
\hline
\end{tabular}

* The variable is significantly different $(p<0.05),{ }^{* \star}$ The variable is highly significant $(p<0.01),{ }^{n s}$ The variable is not significant $(p>0.05)$. Values with different superscript letters $\left({ }^{a, b, c}\right)$ in the columns are significantly different.

Table 4. Spearman Correlation coefficients between age and number of leukocytes with other study variables in horses naturally infected in grazing in a humid warm climate.

\begin{tabular}{|c|c|c|c|c|c|c|c|c|}
\hline & \multicolumn{4}{|c|}{ Age } & \multicolumn{4}{|c|}{ Leukocytes } \\
\hline & Rainy & Cold & Dry & Overall & Rainy & Cold & Dry & Overall \\
\hline EPG & $n s$ & $n s$ & $n s$ & $-0.06^{n s}$ & $n s$ & $0.42^{* \star}$ & $n s$ & $0.21^{*}$ \\
\hline Leucocytes & $n s$ & $-0.64^{* *}$ & $-0.44^{* *}$ & $-0.32^{* *}$ & 1 & 1 & 1 & 1 \\
\hline Lymphocytes & $-0.54^{\star \star}$ & $-0.64^{\star \star}$ & $-0.46^{\star \star}$ & $-0.52^{\star \star}$ & $0.39^{\star \star}$ & $0.75^{\star \star}$ & $0.74^{\star \star}$ & $0.59^{\star \star}$ \\
\hline Neutrophils & $n s$ & $n s$ & $n s$ & $0.02^{n s}$ & $0.81^{\star *}$ & $0.54^{\star \star}$ & $0.55^{\star \star}$ & $0.73^{\star *}$ \\
\hline Eosinophils & $n s$ & $n s$ & $0.33^{*}$ & $-0.04^{n s}$ & $0.39^{\star \star}$ & ns & $n s$ & $0.32^{* *}$ \\
\hline $\lg A C(\%)$ & $0.34^{*}$ & $n s$ & $0.28^{*}$ & $0.25^{\star \star}$ & $n s$ & $-0.32^{*}$ & -0.34 & $-0.13^{n s}$ \\
\hline $\lg A S(\%)$ & $n s$ & $n s$ & $0.37^{\star *}$ & $0.28^{* *}$ & $n s$ & $n s$ & -0.30 & $-0.08^{n s}$ \\
\hline
\end{tabular}

* The correlation is significantly different $(p<0.05),{ }^{* *}$ The correlation is highly significant $(p<0.01),{ }^{n s}$

The correlation is not significant $(p>0.05)$. EPG. Eggs per gram of feces 
cyathostomins (Andersen et al. 2013); so, establishing the anthelmintic treatments in rainy and cold season could be a good strategy to reduce the number of EPG during the seasons of the highest risk of re-infection. This fact would allow achieving a low number of EPG after the last deworming and thus prolonging the frequency between anthelmintic treatments. This action could improve the health of the herd, which would avoid the clinical symptoms such as diarrhea, chronic weight loss, colic and an acute larval cyathostominosis often characterized by fatal diarrhea (Von Samson-Himmelstjerna 2012). However, the strongyle egg counts won't contribute to increase the EPG total counts; since their prepatent period could be as long as 6 to 12 months (Andersen et al. 2013).

\section{Eggs per gram of feces and immune response} Immunological and parasitological parameters showed large inter-season variations. The environmental conditions are important factors that determine the development of the infective stages of nematodes; so that high number of EPG counts in the rainy season promote the contamination of pastures with free-living stages (Navarro dos Santos et al. 2012). Therefore in warm and humid climates like in Brazil, fecal mass plays an important role as a reservoir of larvae that survive with the remaining moisture and that can parasitize animals during the dry season. Data from studies conducted in Germany suggest that the risk of infections with nematodes is relatively small in this country where environmental conditions do not favor the larval development (Schneider et al. 2014). Conversely, in the present study, the lowest number of EPG occurred in the months with the lowest rain (dry season). This coincided with higher values of PCV and TPP and a lower production of IgA against cyathostomins. Probably the low re-infection provokes the reduction of the $\operatorname{IgA}$, because it requires the stimulation of the infection to maintain the high levels of humoral immune response. Interestingly, in another study with African equines a positive correlation between the number of EPG and IgA level, was recorded (Tombak et al. 2020). The lowest numbers of neutrophils were also observed during dry season.
This implies that the lower re-infection during the low rainfall months allows horses improving their health indexes (higher PCV and TPP and lower number of EPG counts), which increases in the dry season compared to the rainy seasons. However, the changes in PCV did not reach extreme levels that represent health problems during the study, since the observed values (39 $\pm 4.3 \%$ ) were within the normal range (Lumsden et al. 1980). In other study, it was shown that parasitic burden did not seriously affect the health of horses and was not correlated with the body condition (Burden et al. 2010), therefore other aspects are likely to be more important; for example, the nutrition of the animals (Valdéz-Cruz et al. 2013). It is important to consider not deworming unnecessarily the whole herd; but using other control strategies, such as the selective treatment, that allows the individual treatment, when the animals really need it.

Females had higher fecal GIN egg counts than males, which was also reported in another study in Spain (Francisco et al. 2009). This parasitological response was surely because the females have greater susceptibility during lactation and can be a source of environmental contamination (Martins et al. 2018), and in the study some females were lactating. In this case, only TPP values were different between males and females, which suggests that females produce a greater amount of protein in response to GIN infection; however, no differences in cellular and humoral values were found by gender. Other studies reported greater differences between horse breeds; however, the gender and age of the animals were only partially related to the acquired resistance (Gras et al. 2011).

Horses having a high rate of infection regularly show serious health problems (Tavassoli et al. 2010). However, it has been indicated that helminths stimulate a strong immune response that lead to reduce their establishment and persistence in their hosts. In addition, helminths are immunomodulatory and are capable of interfering with immune and inflammatory mechanisms of the host (Moreau and Chauvin 2010).

In the present study was observed that young horses had less IgA compared to adults and olds, 
which coincides with the results by Perkins and Wagner (2015), who indicated that the immunoglobulin isotype composition in foal serum showed reduced concentrations during the first year of life. Foal endogenous $\lg$ (4/7) was first detectable by $16-20$ weeks and slowly increased during the first year of life. This finding was also confirmed in the present study by obtaining a positive correlation coefficient between age and IgA concentration.

The high number of EPG of the horses in this study was comparable with the values indicated in other countries, where the main species observed were cyathostomins (Francisco et al. 2009; Nielsen et al. 2010). In Germany, a high prevalence (98.4\%) of the Cyathostominae subfamily was observed, and to a lesser extent ascarids (16.7\%), tapeworms (14.3\%), pinworms $(8.7 \%)$, and Strongyloides $(4.0 \%)$ were also observed (Hinney et al. 2011). In donkeys of Ethiopia $94.9 \%$ of prevalence in Strongylus genus was reported (Ibrahim et al. 2011).

The major changes in the white blood cell counts occurred in time by the effect of the nematode infection (Hubert et al. 2004). The reduction in the number of lymphocytes and neutrophils was also explained by the low re-infection originated by the dry season; since, due to the lower NGI infection, the immune response of the animals is low. On this regard is interesting to mention that in another study, the leukocyte, neutrophils and lymphocytes counts were higher in the group of parasitized horses than in their control group (Hubert et al. 2004). In the same way, another study has indicated an increase in neutrophils, monocytes and eosinophils in nematode infected horses
(Katre et al. 2020).

Immunoglobulins have been used as a tool for the diagnosis of nematode infections (Abo-Aziza et al. 2017); however, in this study, no relationship was observed between IgA levels and EPG values. The high variability found in the number of EPG between individuals and the local action site of $\lg A$ in the mucous membranes and the low periphery levels are some of the explanations for which there was no correlation between $\lg A$ and number of EPG. The only positive correlation of EPG was with leukocytes and neutrophils.

\section{CONCLUSIONS}

High effectiveness of pyrantel pamoate was observed, so strategic nematode control programs must be designed to maintain high effectiveness. The immune response of the horses measured through the IgA values and the total leukocyte and lymphocyte count was a function of season and the age of the horses, but no differences were observed by gender. The state of health measured through the PCV was affected by environmental conditions, which coincided with the number of nematode eggs, especially in the cold season in which the EPG increased.

\section{ACKNOWLEDGEMENTS}

In memory to Rubén Morteo Gómez who will always be with us and granted all the facilities to carry out this study.

\section{LITERATURE CITED}

Abo-aziza FAM, Hendawy SHM, Namaky AHE, Ashry HM (2017) Th1 / Th2 balance and humoral immune response to potential antigens as early diagnostic method of equine Strongylus nematode infection. Veterinary World 10: 679-687.

Andersen UV, Howe DK, Olsen SN, Nielsen MK (2013) Recent advances in diagnosing pathogenic equine gastrointestinal helminths: The challenge of prepatent detection. Veterinary Parasitology 192: 1-9.

Bowman DD (2011) Georgis Parasitología para Veterinarios. 9a Edition. Elsevier. Barcelona, España. 453p. 
Bradford MM (1976) A Rapid and sensitive method for the quantitation microgram quantities of protein utilizing the principle of protein-dye binding. Analytical Biochemistry 72: 248-254.

Burden FA, Du Toit N, Hernandez-Gil M, Prado-Ortiz O, Trawford AF (2010) Selected health and management issues facing working donkeys presented for veterinary treatment in rural Mexico: some possible risk factors and potential intervention strategies. Tropical Animal Health and Production 42: 597-605.

Cardoso CP, Silva BF, Trinca LA, Amarante AFT (2013). Resistance against gastrointestinal nematodes in Crioulo Lageano and crossbred Angus cattle in southern Brazil. Veterinary Parasitology 192: 183-191.

CONAGUA (2020) Servicio Meteorológico Nacional. Normales climatológicas. https://smn.conagua.gob.mx/es/ informacion-climatologica-por-estado?estado=tab. Data consulted: july 21, 2020.

Dobson RJ, Hosking BC, Jacobson CL, Cotter JL, Besier RB, Stein PA, Reid SA (2012) Preserving new anthelmintics: A simple method for estimating faecal egg count reduction test (FECRT) confidence limits when efficacy and / or nematode aggregation is high. Veterinary Parasitology 186: 79-92.

Domínguez-Sánchez C, Cervantes P, Pérez-Rico A, Delgado J, Jiménez L, Aguirre L, Brandariz C, Nuñez L, Cortés O, Farman S, Costa MR, Kelly L, Vega-Pla JL (2015) Estructura genética del caballo local de Veracruz, México, usando microsatélites. Actas Iberoamericanas de Conservación Animal 6: 192-200.

Francisco I, Arias M, Cortiñas FJ, Francisco R, Mochales E, Dacal V, Suárez JL, Uriarte L, Morrondo P, SánchezAndrade R, Díez-Baños P, Paz-Silva A (2009) Intrinsic factors influencing the infection by helminth parasites in horses under an oceanic climate area (NW Spain). Journal of Parasitology Research 2009: ID: 616173. DOI: https://doi.org/10.1155/2009/616173

Fritzen B, Rohn K, Schnieder T, von Samson-Himmelstjerna G (2010) Endoparasite control management on horse farms - lessons from worm prevalence and questionnaire data. Equine Veterinary Journal 42: 79-83.

González-Garduño R, López Arellano ME, Mendoza De Gives P, Arece García J, Marie-Magdeleine C, Torres Hernández G, Oliva Hernández J, Hinojosa-Cuéllar JA (2017) Comparative response of IgA and IgG activity and hematological parameters among four main beef-cattle breeds infected with gastrointestinal nematodes in the warm humid tropic of Mexico. Annals of Animal Science 17: 819-833.

González-Garduño R, Nuncio-Ochoa MGJ, Navarro-Martínez F, Balán FA, Arias Vázquez MS, Paz-Silva A (2015) Intensity of infection with strongylids nematodes in horses from Southeast Mexico. Chilean Journal of Agricultural and Animal Sciences 31: 127-136.

Gras LM, Usai F, Stancampiano L (2011). Strongylosis in horses slaughtered in Italy for meat production: Epidemiology, influence of the horse origin and evidence of parasite self-regulation. Veterinary Parasitology 179: $167-174$.

Hinney B, Wirtherle NC, Kyule M, Miethe N, Zessin KH, Clausen PH (2011) Prevalence of helminths in horses in the state of Brandenburg, Germany. Parasitology Research 108: ID: 1083. DOI: https://doi.org/10.1007/ s00436-011-2362-z

Hubert JD, Seahorn TL, Klei TR, Hosgood G, Horohov DW, Moore RM (2004) Clinical signs and hematologic, cytokine, and plasma nitric oxide alterations in response to Strongylus vulgaris infection in helminth-naïve ponies. The Canadian Journal of Veterinary Research 68: 193-200.

Ibrahim N, Berhanu T, Deressa B, Tolosa T (2011) Survey of prevalence of helminth parasites of donkeys in and around Hawassa town, Southern Ethiopia. Global Veterinaria 6: 223-227.

Katre R, Waghmare SP, Pajai KS, Hajare SW, Ali SS, Game H (2020) Haemo-biochemical alteration in gastrointestinal nematode infection in horses. The Pharma Innovation 9: 15-17. 
Khan MA, Roohi N, Rana MAA (2015) Strongylosis in equines: a review. The Journal of Animal and Plant Science 25: $1-9$.

Lumsden JH, Rowe R, Mullen K (1980) Hematology and biochemistry reference values for the light horse. Canadian Journal of Comparative Medicine 42: 32-42.

Martins N, Pinto D, Cunha L, Mueller A, Villarreal J, Bruhn F, Nizoli L (2018) Occurrence of helminths regarding the age and reproductive status in crioulo breed mares from the south region of Rio Grande do Sul, Brazil. Science and Animal Health 6: 218-227.

Matthews JB (2014) Anthelmintic resistance in equine nematodes. International Journal for Parasitology: Drugs and Drug Resistance 4: 310-315.

Moreau E, Chauvin A (2010) Immunity against Helminths: Interactions with the host and the intercurrent infections. Journal of Biomedicine and Biotechnology 2010: 9. ID: 428593. DOI: https://doi.org/10.1155/2010/ 428593

Musa MT, Abdel Wahab MB, Adam ME (2016) Internal and external parasitic infections of equines in South Darfur state, Western Sudan. University of Khartoum Journal of Veterinary Medicine and Animal Production 7: 1-9.

Navarro dos Santos C, Soares de Souza L, de Freitas Vieira V, Pinheiro J, de Azevedo Rodrigues M (2012) Cyathostomin larvae: presence on Brachiaria humidicola grass during the rainy and dry seasons of Brazil. Revista Brasileira de Parasitologia Veterinaria 2961: 28-31.

Nielsen MK, Baptiste KE, Tolliver SC, Collins SS, Lyons ET (2010) Analysis of multiyear studies in horses in Kentucky to ascertain whether counts of eggs and larvae per gram of feces are reliable indicators of numbers of strongyles and ascarids present. Veterinary Parasitology 174: 77-84.

Perkins GA, Wagner B (2015) The development of equine immunity: Current knowledge on immunology in the young horse. Equine Veterinary Journal 47: 267-274.

SAS (2017) SAS/STAT User's Guide. Release 6. Inst., S. (ed.),. Cary, NC, USA. 1848p.

Schneider S, Pfister K, Becher AM, Scheuerle MC (2014) Strongyle infections and parasitic control strategies in German horses - a risk assessment. BMC Veterinary Research 10. ID: 262. DOI: https://doi.org/10.1186/ s12917-014-0262-z

Seyoum Z, Tesfaye M, Derso S (2015) Prevalence, intensity and risk factors of infestation with major gastrointestinal nematodes in equines in and around Shashemane, Southern Ethiopia. Tropical Animal Health and Production 47: 1515-1521.

Tavassoli M, Dalir-Naghadeh B, Esmaeili-Sani S (2010) Prevalence of gastrointestinal parasites in working horses. Polish Journal of Veterinary Scicences 13: 319-324.

Thienpont D, Rochette F, Vanparijs OFJ (2003) Diagnosing helminthiasis by coprological examination. 3th Edition. Janssen Research Foundation. Beerse, Belgium. 215p.

Tombak KJ, Budischak SA, Hauck S, Martinez LA, Rubenstein DI (2020) The non-invasive measurement of faecal immunoglobulin in African equids. International Journal for Parasitology: Parasites and Wildlife 12: 105-112.

Valdéz-cruz MP, Hernández-Gil M, Galindo-Rodríguez L, Alonso-Díaz MÁ (2013) Gastrointestinal nematode burden in working equids from humid tropical areas of central Veracruz, Mexico, and its relationship with body condition and haematological values. Tropical Animal Health and Production 45: 603-607

Von Samson-Himmelstjerna G (2012) Anthelmintic resistance in equine parasites - detection, potential clinical relevance and implications for control. Veterinary Parasitology 185: 2-8. 